\title{
Phylogenetics and Conservation in New Zealand: The Long and the Short of It
}

\author{
Steven A. Trewick and Mary Morgan-Richards
}

\begin{abstract}
Phylogenetic trees represent the evolutionary relationships of taxa at the branch tips. Although long branches in a tree can arise because a taxon has no close relatives, they can also result from other processes; care is needed when inferences are made from the shape of a phylogeny. New Zealand has many endangered species and some biologists infer high evolutionary distinctiveness of these endemics. Although there is evidence that some New Zealand birds are phylogenetically distinct using them as a calibration of continental drift vicariance has been misleading. In reptiles, extensive conservation resources have been devoted to management of tuatara, in part due to their phylogenetic distinctiveness as sister to all lizards and snakes. The lack of extant diversity in the tuatara lineage could indicate that this line will contribute little to biodiversity in the future, in contrast to New Zealand squamates that have radiated to occupy diverse habitats. All life on earth has a common ancestor so phylogenetic distinctiveness of any organism must be viewed in the context of the whole. A logical extension of building conservation strategy this way is a focus on microscopic life because microbes encompass far more diversity than do eukaryotes. Furthermore, this diversity can be captured in microbiomes such as soils and marine sponges that include many species and many phyla. To achieve true phylogenetic representation of life on earth requires conservation of ecosystems. Although large animals and plants are traditionally chosen as flagship species, a more impartial approach might focus on microbes that underpin ecosystem function.
\end{abstract}

Keywords Evolutionary potential $\bullet$ Kākāpō $\bullet$ Tuatara $\bullet$ Sponges $\bullet$ Microbiomes

\footnotetext{
S.A. Trewick $(\bowtie) \bullet$ M. Morgan-Richards

Ecology Group, Institute of Agriculture and Environment, Massey University,

Private Bag 11-222, Palmerston North, 4442 New Zealand

e-mail: s.trewick@massey.ac.nz; m.morgan-richards@massey.ac.nz 


\section{Introduction}

Variously described as a diversity hotspot, Gondwanan remnant and paradise lost to invasive species (e.g. Daugherty et al. 1993; Gibbs 2006; Lee et al. 2006), New Zealand presents enormous challenges for conservation (DOC 2000). Key is the question of how to prioritise management effort and funding (e.g. Cullen 2012; Walker et al. 2012) and amongst the available tools for prioritisation is phylogenetics (Margules and Pressey 2000; Purvis et al. 2005; Rolland et al. 2011). Here we consider just two aspects of phylogeny in conservation with reference to New Zealand biota. First we examine the implications of long branches in phylogenetic trees and the biological information they might contain. We highlight the role of taxon sampling in the identification of long branches and the biological significance of phylogenetic distinctiveness. We then consider a broader view of phylogenetic diversity including microorganisms that are rarely considered in conservation planning (Nee $2004 a, b)$. As the fountain of phylogenetic diversity, microbial diversity, which also underpins ecological diversity and ecosystem function, provides scaling for conservation that is not influenced by size, scarcity and marketable appeal. We argue that the logical extension of a strict application of conservation prioritisation using phylogenetic distinctiveness must result in a focus on unicellular organisms that are not traditionally emphasised. Using data from marine sponges we provide an example of a micro-environment that is rich in phylogenetic diversity. Diversity-rich microbiomes may be the much-needed foci for conservation of higher order biodiversity.

\section{Long Branches and Their Biological Meaning}

An avowed objective of conservation is the maintenance of maximum evolutionary potential (Avise 2005). But as it is not feasible to confidently predict which lineages will be successful in the future, not least because much that happens in biology is subject to stochasticism. Retaining maximum evolutionary history might be an alternative and better, or at least achievable strategy. In this context, taxa at the tips of long branches attract special attention although a similar level of investment in representatives of speciose clades is also required to conserve the history represented by those lineages too.

On the face of it taxa on long branches appear to represent long evolutionary history. But what is a long branch and what information does it carry (or not carry) about the past?

Long branches on phylogenetic trees result from one of three processes:

1. The lineage might have evolved without lineage splitting increasing species diversity. This would involve each new species replaces its immediate ancestor in succession.

2. The branch/lineage experienced an accelerated rate of molecular evolution in relation to all others, at the locus providing the (presumed) phylogenetic signal.

3. The clade that includes the taxon in question has been extensively pruned so that near relatives have been removed. 
Processes 1 and 2 could in themselves constitute evidence of distinctive unusual evolutionary mechanisms that demand conservation; however this would depend on verification. For 1, a detailed fossil record would be required to refute the alternative and more likely hypothesis that the lineage evolved via lineage splitting (Gould and Eldredge 1993) but has been subject to extinction (as in 3) (Vaux et al. 2015). For 2, analysis of other gene sequences would be needed to identify if rate variation was consistent across the genome or was due to gene-specific positive selection. If rate variation is locus-specific it is highly likely that resulting data are not tree-like, and hence phylogenetically misleading though interesting in other ways.

Process 3 can be further subdivided by the cause of the deficiency of closely related taxa. The absence of close relatives could result simply from experimental failure to sample extant species that are more closely related, or might represent extinction of other members of the clade at any time in the past. These alternatives can be readily tested by inclusion of all plausible extant relatives in phylogenetic analyses. Where a "clade" is truly represented by a singleton (i.e. no closer relatives exist on the planet), then the sister group corollary has to be considered. Every lineage exists as a sister to another lineage or clade so that taxa at the tips of long branches are not intrinsically more important in evolutionary terms than those on short branches. This can be readily demonstrated by the simple expedient of pruning an existing data set (Fig. 1a).

The role of variation in rates of molecular evolution in producing long branches can be determined from the underlying data. In ideal circumstances, if phylogenetic reconstruction has used appropriate models of DNA evolution and informative outgroups, trees with long branches resulting from rate acceleration are expected to look quite different from those that simply lack near relatives (Fig. 1b). Phylogenetic trees inferred from molecular data use sampling at time zero (the present) so it is expected that sequences will change subject to some local rate variation around a mean for a given taxon group, gene etc. with a relatively small variance (see Bromham and Penny 2003). Thus, typically, a phylogeny that is subject to local rate variation will appear unbalanced; branch tips will not be adjacent or nearly so (Fig. 1b). An obvious situation in which local branch rate might result in a long branch and/or phylogenetic misplacement of the node, exists when genes used for tree estimation are under positive/diversifying selection in some taxa, but are constrained in others.

The relative length of a branch in a phylogenetic tree might be used to direct conservation strategy in three distinct ways.

1. Species on long naked branches in phylogenies that include the appropriate sample of extant taxa can be taken as important representation of groups that were once more diverse, and that represent evolutionary potential that is different from the sister clade.

2. Species on long branches for which there is phylogenetic evidence of lineage specific acceleration of molecular evolution can be taken as representing interesting genomes with unusual genetic properties. A long branch of this type might result from genome-wide rate increase (compared to sister group) or locusspecific effects and represent specific adaptive traits. 


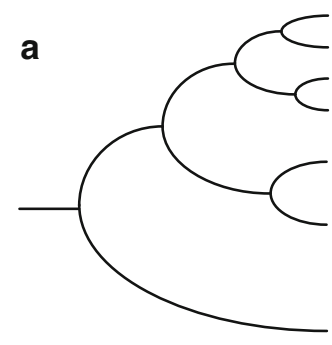

b
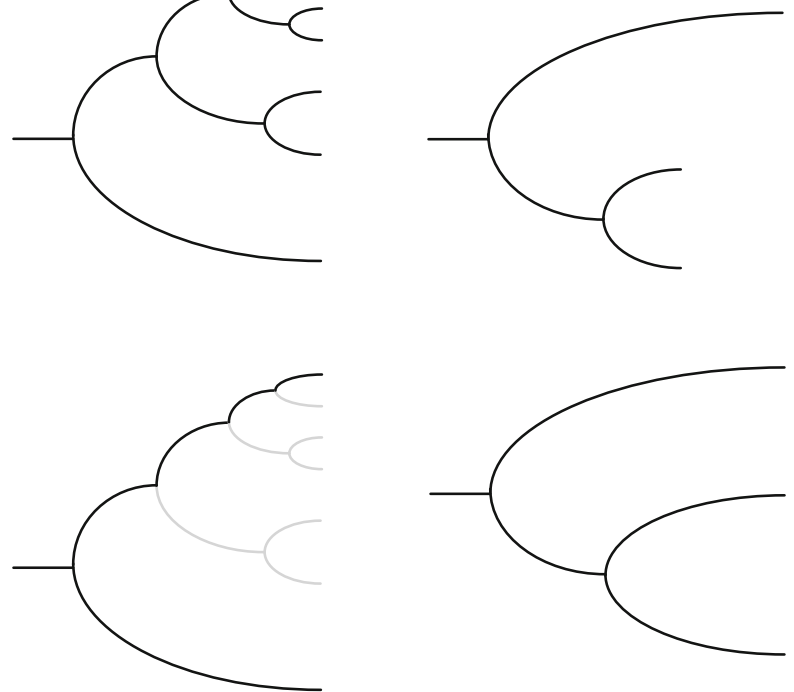

Fig. 1 Phylogenetic trees illustrate the evolutionary relationships of species. a Influence of sampling on apparent cladogenesis. Pruning branches (grey) from the top phylogeny results in an apparent long branch for the remaining clade singleton (bottom). b Long branches where (top) unbalanced branch lengths result from different rates of molecular evolution at the gene used to make the tree (or wrong outgroup), and (bottom) equal rates of molecular evolution but different rates of speciation

3. Taxa on short branches nested within a clade, but accompanied by other character information on their distinctiveness (morphology, behaviour, habitat type) could be important representatives of evolutionarily innovative lineages.

For large organisms such as birds and mammals and many plant groups it is relatively easy to know how complete is taxon sampling amongst extant biota. In most cases existing taxonomy and checklists provide strong indicators. However, for smaller organisms, classification is often incomplete, taxa are not described and there are many instances of misclassification because character analysis has been lacking. Thus the significance of branch length is tempered by other information and the most phylogenetically diverse types of life on earth are severely under-represented.

\section{Birds on Long Branches}

Our understanding of bird evolution has been advanced rapidly through the use of molecular phylogenies that have demonstrated that birds began to diversify before the K/Pg boundary (Cretaceous/Palaeogene, formerly K/T; about 65 million years 
ago) (e.g. Penny and Phillips 2004). This finding countered opinions established on a formerly deficient fossil record that extinction of dinosaurs and associated fauna at $\mathrm{K} / \mathrm{Pg}$ provided the impetus for subsequent bird diversification. Much of this phylogenetic work has centred on analysis of mitochondrial genome data (mitogenomics; e.g., Pratt et al. 2009; Morgan-Richards et al. 2008; Slack et al. 2007; Gibbs and Penny 2010), although multilocus nuclear data have started to be generated from high throughput DNA sequencing (NGS) and advanced bioinformatics (e.g., Hackett et al. 2008; Jetz et al. 2012; McCormack et al. 2013). Recent analyses have focused on teasing out the timing of lineage formation using calibration with fossils or other information. Naturally sampling has been directed at representation of maximum putative taxonomic diversity, especially at the level of orders, and within this, families. A curious artefact of this approach is a sampling bias reflecting not biology but researcher location. For instance, in the analysis of Pacheco et al. (2011) there are many New Zealand birds at the tips of long branches. New Zealand birds are included as representatives of four orders; Strigiformes (owls), Psittaciformes (parrots), Coraciiformes (rollers and their relatives) and Passeriformes (song birds), and three of these represent lineages estimated to have diverged before the K/Pg boundary (Fig. 2).

On the face of it, this is exciting evidence that New Zealand harbours ancient bird lineages that could be seen as consistent with the hypothesis that the continen-

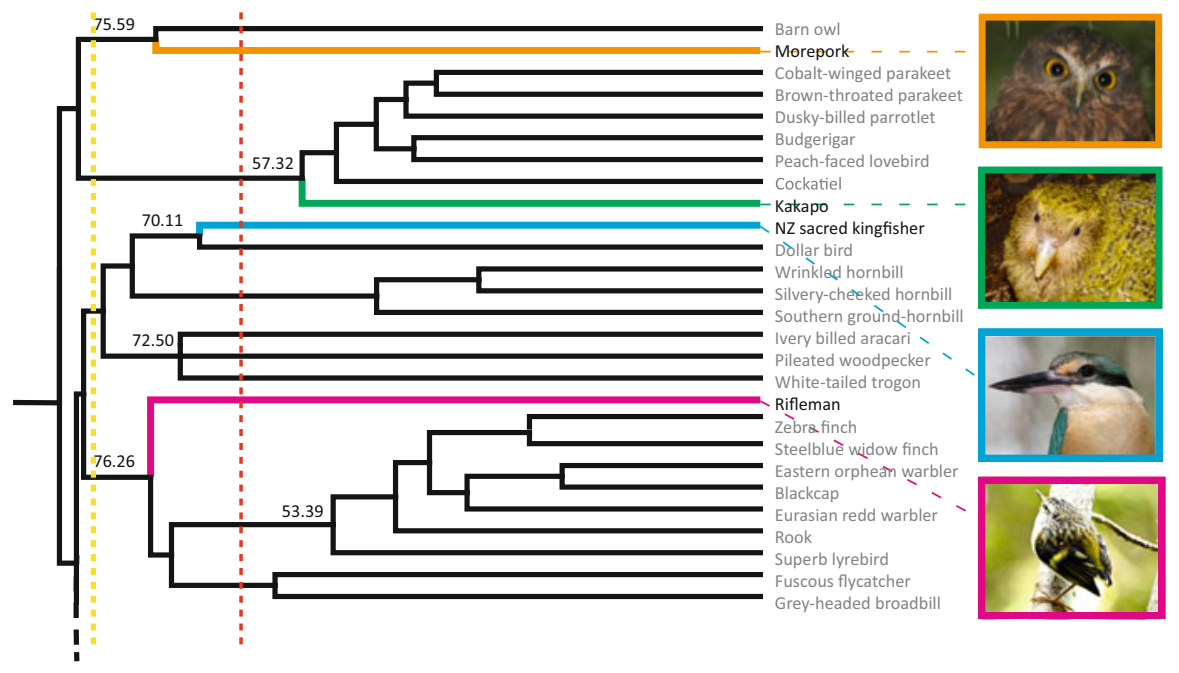

Fig. 2 New Zealand birds on long branches. Part of the mitogenomic phylogeny of modern birds redrawn from Pacheco et al. (2011), featuring clades arising from the deepest nodes in the tree. The New Zealand species are indicated on the relevant branches; Morepork/Ruru (Ninox novaeseelandiae) orange, kākāpō (Strigops habroptilus) green, NZ sacred Kingfisher/Kōtare (Todiramphus sanctus) blue, rifleman/ tītipounamu (Acanthisitta chloris) pink. Numbers at nodes are estimated ages in millions of years (Pacheco et al. 2011). Vertical yellow and red dashed lines indicate timing of Gondwana/Zealandia separation and K/Pg boundary respectively (Images (C) Sabines's Sunbird, Mnolf, Fir0002, digika (respectively) - Wikimedia Commons) 
tal crust of New Zealand has maintained deep phylogenetic diversity since isolation of Zealandia from Gondwana (Trewick et al. 2007; Landis et al. 2008). However, including more bird species in the analysis and information about the distributions of closely related species (within the same genus and family) refutes an inference of Gondwana origin for most of these. For example morepork/ruru (Ninox novaeseelandiae) and NZ sacred kingfisher/kōtāre (Todiramphus sanctus) are species also found outside of New Zealand (Trewick and Gibbs 2010; Goldberg et al. 2011). In further analyses, the rifleman/ tītipounamu (Acanthisitta chloris) does remain sister to the rest of the Passerine clade but the dates inferred are more recent than plate tectonic separation ( 40 MYA. Jarvis et al. 2014). An analytical problem associated with long branches in phylogenetic trees is the tendency for them to be drawn to the basal nodes. This "long branch attraction" is an artefact of repeated nucleotide substitution resulting in character convergence by chance, such that shared derived characters states are not available to counter the effect (see Bergsten 2005). Thus caution is always required when making inferences from long branches that appear to have phylogenetically deep origins.

When biogeographic history is used to calibrate molecular clocks the impression of ancient origins of lineages can be exacerbated. For instance Wright et al. (2008) studied parrot evolution and used the timing of Zealandia/Gondwana breakup ( 80 mya) to calibrate their molecular clock analysis. This approach rested on the assumption that continental drift resulted in the origin of the lineage leading to kākāpō (see Crisp et al. 2011). This is an appealing idea because the shared stratigraphic history of Zealandia and Gondwana is well known (Campbell and Hutching 2011), and the kākāpō (Strigops habroptilus) shows many derived traits not seen in other parrots (e.g. flightless, lek breeding, nocturnal). As a result of this calibration kākāpō and another native New Zealand parrot genus (Nestor) were placed on a branch with its node at about 80 mya, apparently supporting the idea of an ancient New Zealand origin of Strigopoidea (Wright et al. 2008). The reasoning is however circular (Waters and Craw 2006), and the underlying assumption clearly falsified. Wright et al. (2008) themselves noted that some over-sea dispersal of parrot ancestors was required to reconcile all parts of their biogeographic analysis. There is separate direct evidence falsifying the hypothesis that Strigopoidea originated through ancient breakup of Gondwana and Zealandia; the existence of a distinct species of Nestor on the geologically young volcanic Norfolk Island $(\sim 900 \mathrm{~km}$ north of NZ) until European time. Clearly birds in this lineage retained the ability to move substantial distances over water (Christidis and Boles 2008).

More recent analyses using multiple fossil calibrations outside the parrots indicate ancestry of this order (Psittaciformes) is probably more recent than both Gondwana/Zealandia breakup and the K/Pg, (Pacheco et al. 2011; White et al. 2011; Schweizer et al. 2011; Jarvis et al. 2014). Analyses retain the New Zealand Strigopoidea as sister to other extant parrots, but inferences about the timing of evolution of the "unique" traits associated with the tip species (alpine kea, temperate kākā, flightless kākāpō) have little to do with the age of the lineage. Neither the evolution of flightlessness in kākāpō nor the current exclusivity of their phylogenetic branch to New Zealand can be attributed to the base of the lineage; flightless- 
ness might have evolved anytime since formation of the lineage and extinction of other members of this lineage that once existed outside New Zealand could have occurred at any time in the past (see Fig. 1a).

Fossil parrot bones have recently been identified in New Zealand dating to between 16 and 19 million years ago (Worthy et al. 2011). These have some morphological features in common with the genus Nestor (kākā and kea) that are not shared with living Australian parrots. There is, however, no available analysis testing the plausibility of alternative systematic classification, and current evidence does not preclude the former existence of Nestor-like parrots (Strigopoidae) in past Australia or Antarctica; both are large landmasses that could have supported supposedly New Zealand bird lineages.

Kōtare (NZ Sacred kingfisher) and Morepork/Ruru (owl) at the tips of long branches (Pacheco et al. 2011) can readily be shown to offer spurious information about the New Zealand biota. Both species also occur outside New Zealand, and have many near relatives around the world. Thus, where a lineage is represented by high diversity, the implications of long branches can be readily assessed, but truly sparse lineages (in the extant biota) remain open to question. In contrast, short edges are readily understood, but as morphological and behavioural evolution is not clocklike, species with numerous unusual characteristics might have unexpected close relatives. For example, the extinct New Zealand eagle (Harpagornis moorei) was the largest eagle known in the world although it shared a common ancestor with the Australian Little eagle (Hieraaetus morphonoides) just a few million years ago (Bunce et al. 2005). Similarly, the takahē (Rallidae, Porphyrio hochstetteri) is flightless and the largest of its family, yet is closely related to a common flying species (Trewick 1997; Garcia-R et al. 2014).

\section{On a Reptilian Limb}

The native New Zealand biota includes only two lineages of scaled reptiles (Squamata), diplodactylid geckos and lygosomine skinks, but it also harbours one other lepidosaurian lineage that is missing from the rest of the world (Rhynchocephalia) (Fig. 3a). So although only two of the four reptilian orders are found in New Zealand, the diversity does span an unparalleled phylogenetic scale for this group of vertebrates. Furthermore, New Zealand species diversity is high but only in some parts of the tree (Fig. 3b).

The tuatara (Sphenodon punctatus) is very clearly out on a phylogenetic limb and naturally this has resulted in much research interest on its ecology (Towns et al. 2007; Mitchell et al. 2010), reproduction (Cree et al. 1992; Cree et al. 1995; Miller et al. 2009), parasites, immunology (Miller et al. 2007; Godfrey et al. 2010), phylogeography (Hay et al. 2009) and conservation (Daugherty et al. 1990). The node uniting Sphenodon with the geckos and skinks may date to Triassic time ( $>200$ mya), although that does not mean that geckos or skinks or Sphenodon originated then. In terms of phylogenetic sampling, molecular data for New Zealand lepido- 


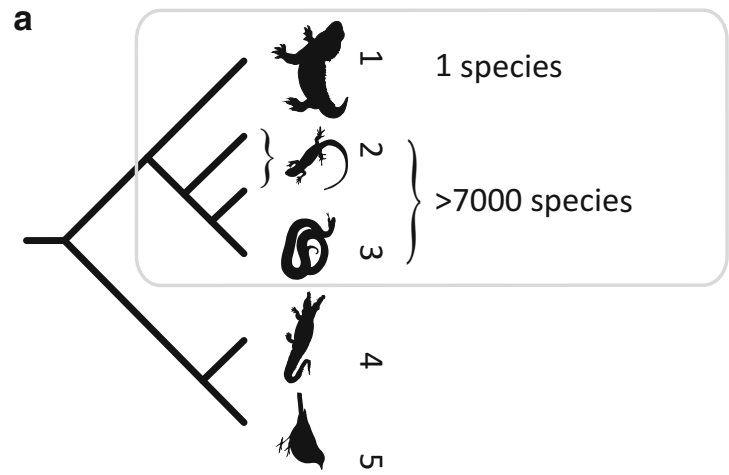

b

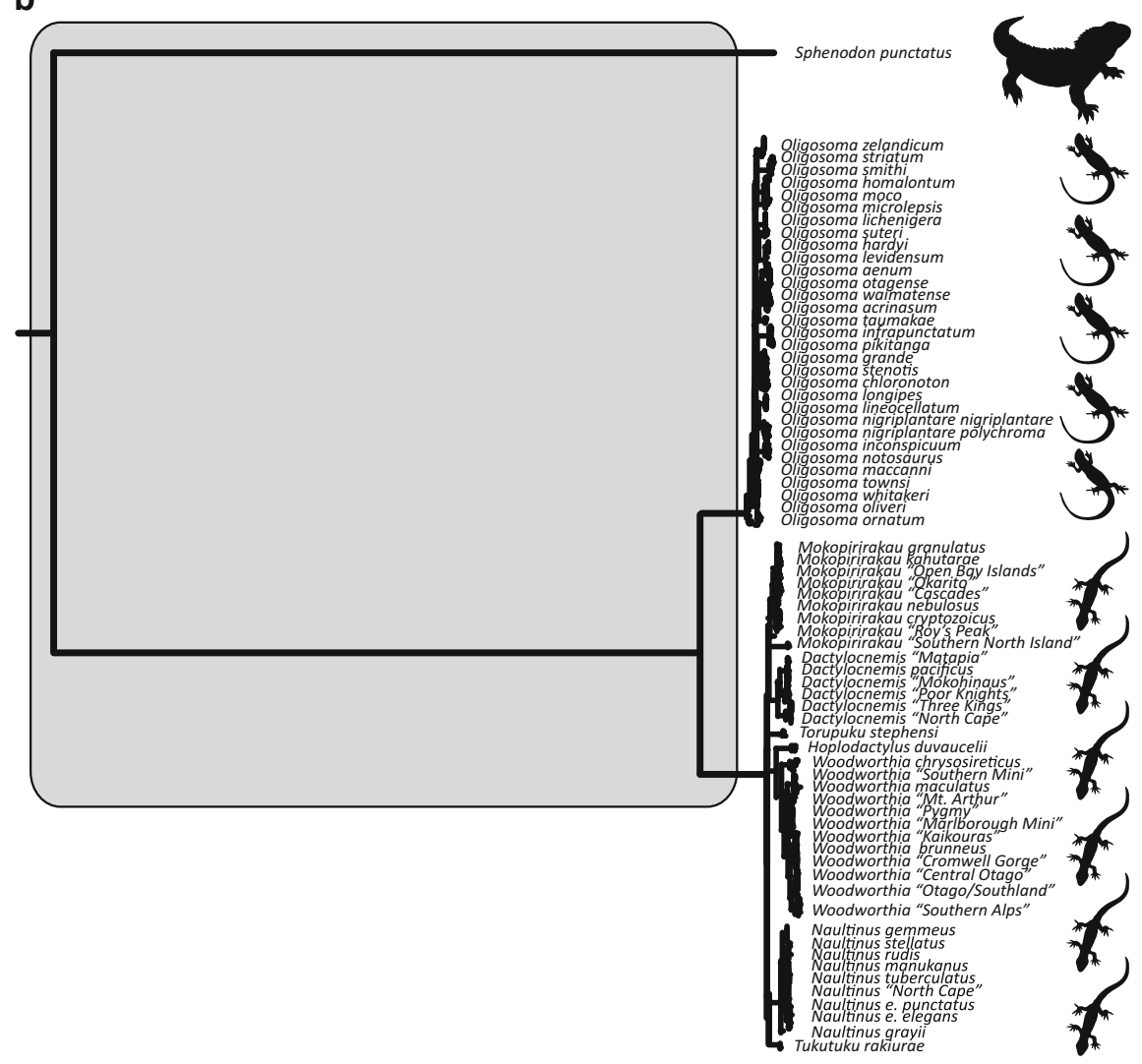

Fig. 3 a Cladogram of Lepidosauria (grey box outline) and related lineages 1 . Rhynchocephalia; 2. Lizards; 3. Snakes; 4. Crocodiles; 5. Birds. b Phylogenetic tree for all New Zealand Lepidosauria inferred using Maximum Likelihood analysis of mtDNA ND2 sequences from Genbank with GTR model (RAxML- Stamatakis 2006) comprising the single extant species of Rhynchocephalia (Hay et al. 2009), 36 species of gecko (Nielsen et al. 2011), and 40 species of skink (Chapple et al. 2009). The grey filled box indicates the region of the tree that provides no phylogenetic or biogeographic information about the lineages 
sauria is rich, with substantial studies that have drawn on many years of expert searching (Chapple et al. 2009; Nielsen et al. 2011). There is little likelihood that major lineages are missing from the analysis through failed sampling. The sampling of likely relatives from outside New Zealand is also probably now sufficient to provide confidence that the gecko and skink radiations are each monophyletic and endemic.

As a representative of a lineage (Rhynchocephalia) that has been otherwise pruned out, Sphenodon does have important conservation status because a single species extinction would result in the loss of the entire lineage, not just in New Zealand but across the globe. In contrast, New Zealand skinks and geckos would have to undergo extinction of numerous species before their respective stem lineages were lost, and even then they would be lost only in New Zealand; related skinks and geckos elsewhere would retain the evolutionary potential of the group.

But this sort of thing must have been happening since the dawn of life on earth, and in terms of taxonomic, biogeographic, ecological, and metabolic diversity, the rhynchocephalids are already extinct. Sphenodon is sadly a museum piece that tells us as little about evolution of reptiles as it tells us about New Zealand biogeography. Sphenodon does say something about the influence of extinction on biodiversity but gives only a tentative hint of the role of natural selection in this process. The global demise of rhynchocephalia (Jones 2008) corresponds with diversification of squamates, and though it is tempting to see evolutionary cause and effect, there is currently no strong evidence for this (Evans and Jones 2010). However, in New Zealand, extant geckos and skinks appear to have diversified from the Miocene onwards (Chapple et al. 2009; Nielsen et al. 2011), whereas Sphenodon did not (or lost diversity as fast as it gained it). Even though there is tantalising evidence that an ancestor of the tuatara might have been present in New Zealand in the Miocene (Jones et al. 2009), there is no evidence for Sphenodon diversification. Even amongst extensive Holocene fossils, that include representatives of many vertebrate species extinguished soon after arrival of humans, there is no additional Sphenodon diversity (Hay et al. 2008).

Because it is already rare and restricted to habitat-modified offshore islands, Sphenodon conservation does not capture broad ecosystem diversity, although it is host to an endangered species of tick (Miller et al. 2007). Conversely, the gecko and skink lineages occupy diverse habitats in forested and open situations from coastline to alpine zone; preservation of either or both of those lineages would result in conservation of ecological diversity across New Zealand. New Zealand geckos are biologically interesting because of their viviparous mode of reproduction and ability to occupy alpine habitat; traits that are unique to the lineage and thus of conservation significance.

\section{Long Branches and Phylogenetic Diversity}

A measure of a species' expected contribution to genetic, or evolutionary distinctiveness is derived from its position in a phylogeny that can be used to place a value on that taxon (see chapters in this book). And as all life on earth has a common 
ancestor (Darwin 1859; Theobald 2010), we can consider the phylogenetic value of any species in the context of the whole (Fig. 4). This view of life based on DNA sequences of full genomes reveals that phylogenetic diversity is dominated by microscopic organisms and conservation of any visible life (fungi, plants, animals) preserves very little evolutionary distinctiveness (Fig. 4; Ciccarelli et al. 2006). Thus, as a starting point in the application of phylogenetics to conservation we should put equal resources into maintaining diversity within the three major lineages (or long branches): Bacteria, Archaea and Eukarya. However, the only species we know sufficiently well to recognise a decline and have knowledge to remedy are eukaryotes. In addition, it is the habitats provided by multicellular organisms that

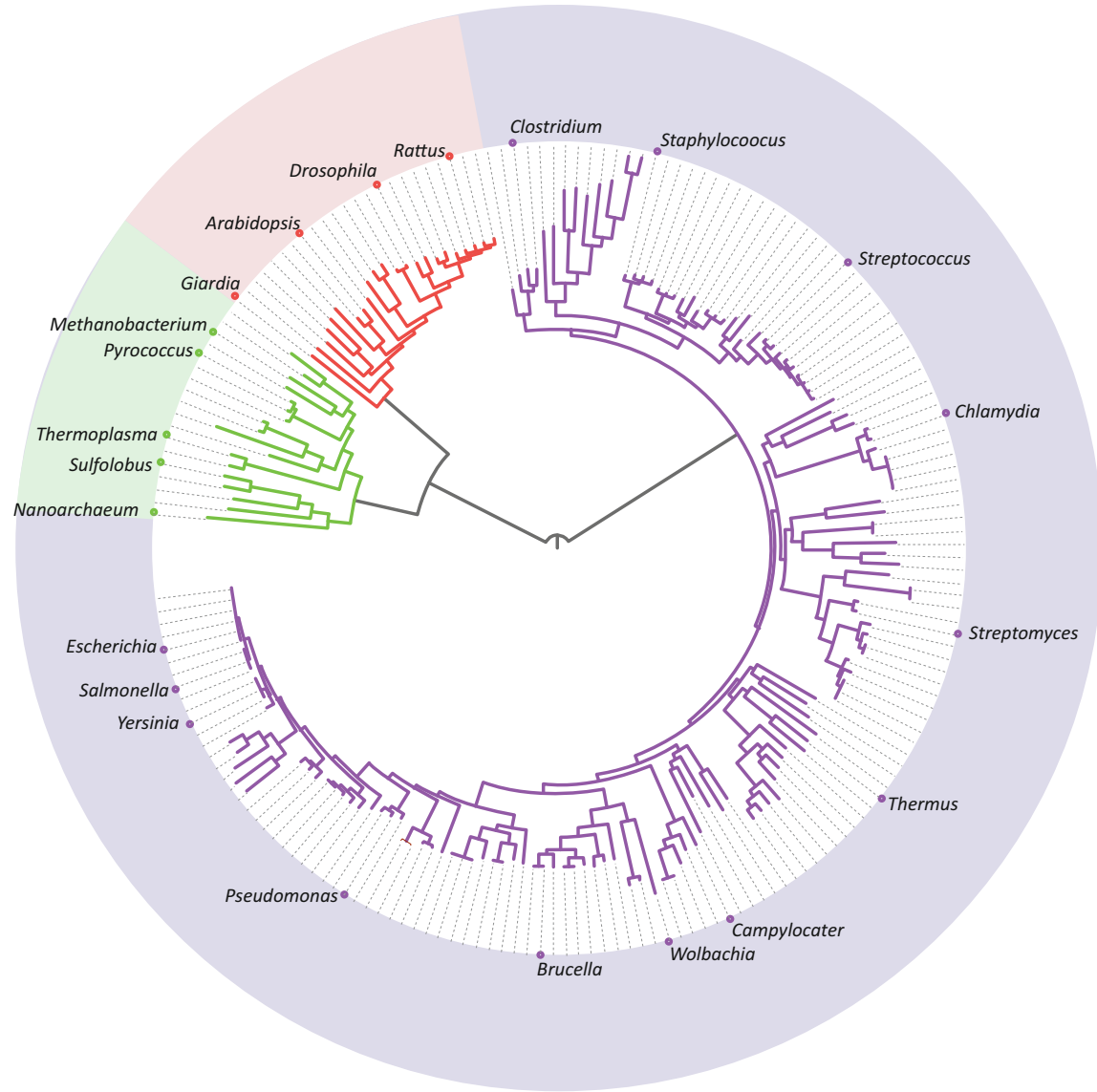

Fig. 4 Phylogenetic diversity on Earth is dominated by microscopic organisms, as revealed by the tree of life based on 31 universal protein families (Redrawn from Ciccarelli et al. 2006). Branch lengths give an indication of the extent of diversity and lineage age. Note the very shallow branches among popular large creatures (red clade). Some of the more widely known microbes are labelled but every branch represents a distinct taxon 
we have invested resources into studying; habitats that host numerous interesting lineages of Bacteria and Archaea (Eckburg et al. 2005).

Thousands of low-abundance taxa account for most of the observed phylogenetic diversity in any environment. This "rare biosphere" contains a large proportion of phylogenetic diversity and represents an enormous contribution to genetic distinctiveness and evolutionary innovation (Sogin et al. 2006; Nee 2004a). After Anton von Leeuwenhoek first looked at bacteria in lake water and material scraped from his teeth in the seventeenth century, our understanding and appreciation of the distribution and abundance of microorganisms advanced relatively slowly. It is now accelerating rapidly as technological developments allow us to obtain and analyse large amounts of DNA data directly from environmental samples containing large numbers of taxa (Lozupone and Knight 2008). Indeed the current state of technology means that microbial genomes are tractable objects for whole genome sequencing. We will soon know whether the 4957 bacterial taxa found in soil of a commercial apple orchard (Shade et al. 2012) is species rich (but phylogenetically restricted) compared to a marine plankton net sample with 189 species of zooplankton (Machida et al. 2009), or human skin with more than 205 species of bacteria from 19 phyla (Grice et al. 2009). Microbial phenotype arrays allow the gathering of far more precise ecological detail about bacteria than is available for eukaryotes (Bochner 2008). There is also emerging evidence of additional fundamental types of life on Earth (Zakaib 2011).

As an example of the known unknowns, consider New Zealand sponges. Sponges are multicellular (visible) marine animals of the phylum Porifera. In coastal water around New Zealand 733 species of sponges have been recorded from 20 orders (Kelly et al. 2006). As with much of the New Zealand fauna (see Trewick and Morgan-Richards 2009), about $95 \%$ of these are endemic to the region at the species level. However, in themselves these species contribute little directly to global diversity because other closely related species exist elsewhere. Generally sponges are not endangered, although special regions of high diversity that exist in hydrothermal areas and on seamounts are under pressure from benthic trawling (Kelly et al. 2006, and see Gianni 2004).

Nevertheless conservation of any sponge species or even population contributes much more; sponges are home to distinct microbial communities (microbiomes) so the total number of phyla preserved might reach more than 40. Sponges host rich microorganism communities and with next generation DNA sequencing data the number of known bacterial phyla in sponges has recently increased (Webster et al. 2010; Schmitt et al. 2012). Although many of the detected phyla are formally described, such as the Algae, Fungi, Actinobacteria, Chloroflexi (Green non-sulfur bacteria), Cyanobacteria, Nitrospira, and Proteobacteria (Fig. 5), several new ones have also been discovered in sponges (Turque et al. 2010; Webster et al. 2010; Schmitt et al. 2012). A single sponge provides an environment that protects an impressive array of phylogenetic diversity (Taylor et al. 2007). So how can we best conserve the phylogenetic diversity harboured inside sponges? Will one species or one geographic region suffice? 


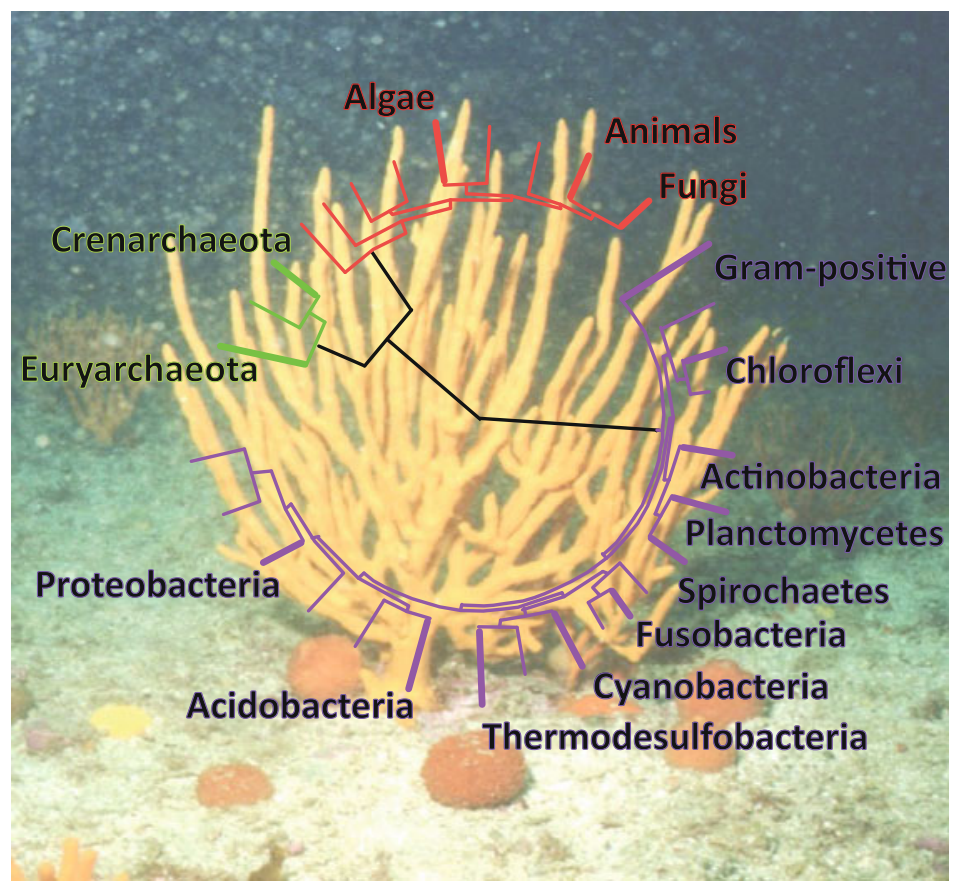

Fig. 5 Each sponge is home to a community of microscopic life that encompasses the range of known phylogenetic diversity on Earth. Here the major phyla found within a sponge microbiome are named on the tree of life. The sponge pictured is Raspailia topsenti, one of five sympatric sponge species studied by Schmitt et al. (2011) from New Zealand coastal waters (Phylogeny redrawn from Ciccarelli et al. 2006. Image (C) Katie Dowle)

Samples from eight locations around the world detected 2567 bacterial taxa representing 22 phyla living inside sponges (Schmitt et al. 2012), while three species of Australian sponge held a total of 2996 bacteria taxa from 36 phyla (Webster et al. 2010). Different sponge species from the same environment possess distinct symbiotic communities. Some components of their bacterial communities appear to be passed from parent to offspring while other components are acquired from the surrounding seawater (Webster et al. 2010; Schmitt et al. 2012). Thus, although a few bacteria are found in all sponges the majority are either host or region specific. For example tropical sponges have microbial communities that are more similar to each other than to the communities in subtropical sponges.

Schmitt et al. (2011) collected five sponge species from a single bay on the coast of New Zealand. By focusing on just the bacteria that are members of the phylum Chloroflexi they compared species diversity between sponges with either high or low microbial abundance, and contrasted this with Chloroflexi diversity in the surrounding seawater. Fifty-eight species of Chloroflexi were recorded from inside the sponges, but only three species in the seawater (Schmitt et al. 2011). About half these taxa were new to science. Ecologically important roles and specific associa- 
tions of Chloroflexi bacteria were inferred for the sponge species with high microbial abundance as the majority of their bacteria fell into sponge-specific and sponge-coral phylogenetic lineages (Schmitt et al. 2011). Thus any single sponge species houses plenty of phylogenetic diversity but if we want to conserve all lineages that are restricted to sponges, we need to conserve more than one sponge species.

\section{Phylogenetic Extremities}

Is it feasible to prioritize for conservation the phylogenetic extremities of life? In fact there is no need to because microbes and peculiar multicellular organisms such as kākāpō, takahē and tuatara are intimately linked. A kākāpō could not function if it and its physical environment were stripped of all microbes. In this respect Kākāpō, like marine sponges are loose assemblies of disparate genomes. Ecosystem function tends to be viewed at the macroscopic scale, but this is only because the tools to visualise the much more extensive and complex underworld have only recently become available. Most, if not all, ecosystem processes are mediated by microscopic life.

\section{Conclusions}

Kākāpō do not need a long phylogenetic branch (thought they are on one) to justify their conservation; their distinctive ecological traits are sufficient reason to protect them. However, it is readily demonstrated, if not quantified, that an environment capable of sustaining a viable population of this species would also sustain many other taxa from soil bacteria to trees. Similarly, takahē (Aves, Rallidae, Porphyrio) deserve protection because of their unusual ecological traits representing evolutionary adaptations lost elsewhere in the world through recent extinction, though takahē are on a much shorter branch from their shared ancestor with a common living species, than is the kākāpō. Species' radiations such as geckos need a quite different strategy that does not rely on long-branch status, to maintain their diversity, unusual traits and associated communities. However, conservation of the substantive part of diversity of life on Earth will benefit from next generation sequencing and emerging bioinformatics tools that can identify assemblages of deeply divergent lineages within definable, manageable biomes. Microbiomes are not well understood, and therefore we are not well placed to determine which environments are home to the greatest phylogenetic diversity. Until we have comparative data, we must strive to maximize retention of ecosystem diversity on Earth, from human guts to forest soils, parrot feathers to rocky shores. To maximise conservation of evolutionary potential on Earth we need to pay more attention to our planet's microbial diversity 
and in doing so maintain ecosystem process to the benefit of the large appealing species that are so popular.

Organic life beneath the shoreless waves

Was born and nurs'd in ocean's pearly caves;

First forms minute, unseen by spheric glass,

Move on the mud, or pierce the watery mass;

(From The Temple of Nature. Erasmus Darwin 1802)

Acknowledgements We are grateful for the assistance of Ananias Escalante for access tree image from Pacheco et al. 2011. Phoenix group members (evolves.massey.ac.nz) provided illuminating discussion. The manuscript was improved by comments from two reviewers and the editors. The authors were assisted by the Marsden Fund (Grant no. 12-MAU-008), administered by the Royal Society of New Zealand.

Open Access This chapter is distributed under the terms of the Creative Commons AttributionNoncommercial 2.5 License (http://creativecommons.org/licenses/by-nc/2.5/) which permits any noncommercial use, distribution, and reproduction in any medium, provided the original author(s) and source are credited.

The images or other third party material in this chapter are included in the work's Creative Commons license, unless indicated otherwise in the credit line; if such material is not included in the work's Creative Commons license and the respective action is not permitted by statutory regulation, users will need to obtain permission from the license holder to duplicate, adapt or reproduce the material.

\section{References}

Avise JC (2005) Phylogenetic units and currencies above and below the species level. In: Purvis A, Gittleman JL, Brooks T (eds) Phylogeny and conservation. Cambridge University Press, Cambridge, pp 76-100

Bergsten J (2005) A review of long-branch attraction. Cladistics 21:163-193

Bochner BR (2008) Global phenotypic characterization of bacteria. FEMS Microbiol Rev 33:191-205

Bromham L, Penny D (2003) The modern molecular clock. Nat Rev Genet 4:216-224

Bunce $\mathrm{M}$ et al (2005) Ancient DNA provides new insights into the evolutionary history of New Zealand's extinct giant eagle. PLoS Biol 3(1):e9

Campbell H, Hutching G (2011) In search of ancient New Zealand. Penguin Group, Auckland

Chapple DG, Ritchie PA, Daugherty CH (2009) Origin, diversification, and systematics of the New Zealand skink fauna (Reptilia: Scincidae). Mol Phylogenet Evol 52:470-487

Christidis L, Boles WE (2008) Systematics and taxonomy of Australian birds. CSIRO Publishing, Canberra, p 200

Ciccarelli FD, Doerks T, von Mering C, Creevey CJ, Snel B, Bork P (2006) Toward automatic reconstruction of a highly resolved tree of life. Science 311:1283-1287

Cree A, Cockrem JF, Guillette LJ Jr (1992) Reproductive cycles of male and female tuatara (Sphenodon punctatus) on Stephens Island, New Zealand. J Zool Lond 226:199-217

Cree A, Thompson MB, Daugherty CH (1995) Tuatara sex determination. Nature 375:543

Crisp M, Trewick SA, Cook LG (2011) Hypothesis testing in biogeography. Trends Ecol Evol 26:66-72

Cullen R (2012) Biodiversity protection prioritization: a 25 year review. Wildl Res 40:108-116 
Darwin C (1859) On the origin of species by means of natural selection, or the preservation of favoured races in the struggle for life, 1st edn. John Murray, London

Daugherty CH, Cree A, Hay JM, Thompson MB (1990) Neglected taxonomy and continuing extinction of tuatara (Sphenodon). Nature 347:177-179

Daugherty CH, Gibbs GW, Hitchmough RA (1993) Mega-island or micro-continent? New Zealand and its fauna. Trends Ecol Evol 8:437-442

DOC (2000) The New Zealand biodiversity strategy. Department of Conservation (DOC); Ministry for the Environment (MfE), Wellington, p 163

Eckburg PB, Bik EM, Bernstein CN et al (2005) Diversity of the human intestinal microbial flora. Science 308(5728):1635-1638

Evans SE, Jones MEH (2010) The origin, early history and diversification of lepidosauromorph reptiles. Chapter 2 in New aspects of mesozoic biodiversity, Lecture notes in earth sciences, vol 132, Springer, pp 27-44

García-R JC, Gibb G, Trewick SA (2014) Deep global evolutionary radiation in birds: diversification and trait evolution in the cosmopolitan bird family Rallidae. Mol Phylogenet Evol 81:96-108

Gianni M (2004) High seas bottom trawl fisheries and their impacts on the biodiversity of vulnerable deep-sea ecosystems. IUCN The World Conservation Union, Gland

Gibbs GC (2006) Ghosts of Gondwana-the history of life in New Zealand. Craig Potton, Nelson

Gibbs GC, Penny D (2010) Two aspects along the continuum of pigeon evolution: a South-Pacific radiation and the relationship of pigeons within Neoaves. Mol Phylogenet Evol 56:698-706

Godfrey SS, Moore JA, Nelson NJ, Bull CM (2010) Social network structure and parasite transmission in a territorial reptile, the tuatara (Sphenodon punctatus). Int J Parasitol 40:1575-1585

Goldberg J, Trewick SA, Powlesland RG (2011) Population structure and biogeography of Hemiphaga pigeons (Aves: Comumbidae) on islands in the New Zealand region. J Biogeogr 38:285-298

Gould SJ, Eldredge N (1993) Punctuated equilibrium comes of age. Nature 366:223-227

Grice EA, Kong HH, Conlan S, Deming CB, Davis J, Young AC, NISC Comparative Sequencing Program, Bouffard GG et al (2009) Topographical and temporal diversity of the human skin microbiome. Science 324(5931):1190-1192

Hackett SJ, Kimball RT, Reddy S et al (2008) A phylogenomic study of birds reveals their evolutionary history. Science 320:1763-1768

Hay JM, Subramanian S, Miller CD, Mohandesan E, Lambert DM (2008) Rapid molecular evolution in a living fossil. Trends Genet 24:106-109

Hay JM, Sarre SD, Lambert DM, Allendorf FW, Daugherty CH (2009) Genetic diversity and taxonomy: a reassessment of species designation in tuatara (Sphenodon: Reptilia). Conserv Genet 11:1063-1081

Jarvis ED et al (2014) Whole-genome analyses resolve early branches in the tree of life of modern birds. Science 346:1320-1331

Jetz W, Thomas GH, Joy JB, Hartmann K, Mooers AO (2012) The global diversity of birds in space and time. Nature 491:444-448

Jones MEH (2008) Skull shape and feeding strategy in Sphenodon and other Rhynchocephalia (Diapsida: Lepidosauria). J Morphol 269:945-966

Jones MEH, Tennyson AJD, Worthy JP, Evans SE, Worthy TH (2009) A sphenodontine (Rhynchocephalia) from the Miocene of New Zealand and palaeobiography of the tuatara (Sphenodon). Proc R Soc 76:1385-1390, London B

Kelly M, Edwards AR, Wilkinson MR, Alvarez B, de Cook SC, Bergquist PR, Buckeridge JS, Campbell H, Reiswig HM, Valentine C (2006) Phylum porifera sponges. In: Gordon DP (ed) The New Zealand Inventory of Biodiversity. Volume 1. Kingdom Animalia: Radiata, Lophotrochozoa, and Deuterostomia. Canterbury University Press, Christchurch

Landis CA, Campbell HJ, Begg JG, Mildenhall DC, Paterson AM, Trewick SA (2008) The waipounamu erosion surface: questioning the antiquity of the New Zealand land surface and terrestrial fauna and flora. Geol Mag 145:173-197 
Lee WG, Allen RB, Tompkins DM (2006) Paradise lost - the last major colonization. In: Allen RB, Lee WG (eds) Biological invasions in New Zealand, vol 186. Springer, Berlin, pp 1-13

Lozupone C, Knight R (2008) Species divergence and the measurement of microbial diversity. FEMS Microbiol Rev 32(4):557-578

Machida RJ, Hashiguchi Y, Nishida M, Nishida S (2009) Zooplankton diversity analysis through single-gene sequencing of a community sample. BMC Genomics 10:438

Margules CR, Pressey RL (2000) Systematic conservation planning. Nature 405:243-253

McCormack JE, Harvey MG, Faircloth BC, Crawford NG, Glenn TC et al (2013) A phylogeny of birds based on over 1,500 loci collected by target enrichment and high-throughput sequencing. PLoS One 8(1):e54848. doi:10.1371/journal.pone.0054848

Miller HC, Conrad AM, Barker SC, Daugherty CH (2007) Distribution and phylogenetic analyses of an endangered tick, Amblyomma sphenodonti. N Z J Zool 34(2):97-105

Miller HC, Moore JA, Nelson NJ, Daugherty CH (2009) Influence of MHC genotype on mating success in a free-ranging reptile population. Proc R Soc Lond B 276:1695-1704

Mitchell NJ, Allendorf FW, Keall SN, Daugherty CH, Nelson NJ (2010) Demographic effects of temperature-dependent sex determination: will tuatara survive global warming? Glob Chang Biol 16:60-72

Morgan-Richards M, Trewick SA, Bartosch-Härlid A, Kardailsky O, Phillips MJ, McLenachan PA, Penny D (2008) Bird evolution: testing the Metaves clade with six new mitochondrial genomes. BMC Evol Biol 8:20

Nee S (2004a) More than meets the eye: earth's real biodiversity is invisible. Nature 429:804-805

Nee S (2004b) Extinction, slime and bottoms. PLoS Biol 2(8):e272

Nielsen SV, Bauer AM, Jackman TR, Hitchmough RA, Daugherty CH (2011) New Zealand geckos (Diplodactylidae): cryptic diversity in a post-Gondwanan 3 lineage with trans-Tasman affinities. Mol Phylogenet Evol 59:1-22

Pacheco MA, Battistuzzi FU, Lentino M, Aguilar RF, Kumar S, Escalante AA (2011) Evolution of modern birds revealed by mitogenomics: timing the radiation and origin of major orders. Mol Biol Evol 28:1927-1942

Penny D, Phillips MJ (2004) The rise of birds and mammals: are microevolutionary processes sufficient for macroevolution? Trends Ecol Evol 19:516-522

Pratt RC, Gibbs GC, Morgan-Richards M, Phillips MJ, Hendy MD, Penny D (2009) Towards resolving deep Neoaves phylogeny: data, signal enhancement and priors. Mol Biol Evol 26(2):313-326

Purvis A, Gittleman JL, Brooks T (2005) Phylogeny and conservation. Cambridge University Press, Cambridge

Rolland J, Cadotte MW, Davies J, Devictor V, Lavergne S et al (2011) Using phylogenies in conservation: new perspectives. Biol Lett 8:692-694

Schmitt S, Deines P, Behnam F, Wagner M, Taylor MW (2011) Chloroflexi bacteria are more diverse, abundant, and similar in high than in low microbial abundance sponges. FEMS Microbiol Ecol 78:497-510

Schmitt S, Tsai P, Bell J, Fromont J, Ilan M, Lindquist N, Perez T, Rodrigo A, Schupp PJ, Vacelet J, Webster N, Hentschel U, Taylor MW (2012) Assessing the complex sponge microbiota core, variable, and species-specific bacterial communities in marine sponges. ISME J 6:564-576

Schweizer M, Seehausen O, Hertwig ST (2011) Macroevolutionary patterns in the diversification of parrots: effects of climate change, geological events and key innovations. J Biogeogr 38:2176-2194

Shade A, Hogan CS, Klimowicz AK, Linske M, McManus PS, Handelsman J (2012) Culturing captures members of the soil rare biosphere. Environ Microbiol 14:2247-2252

Slack KE, Delsuc F, McLenachan PA, Arnason U, Penny D (2007) Resolving the root of the avian mitogenomic tree by breaking up long branches. Mol Phylogenet Evol 42:1-13 
Sogin ML, Morrison HG, Huber JA, Mark Welch D, Huse SM, Neal PR, Arrieta JM, Herndl GJ (2006) Microbial diversity in the deep sea and the underexplored "rare biosphere". Proc Natl Acad Sci U S A 103:12115-12120

Stamatakis A (2006) RAxML-VI-HPC: maximum likelihood-based phylogenetic analyses with thousands of taxa and mixed models. Bioinformatics 22:2688-2690

Taylor MW, Radax R, Steger D, Wagner M (2007) Sponge-associated microorganisms: evolution, ecology, and biotechnological potential. Microbiol Mol Biol Rev 71:295-347

Theobald DL (2010) A formal test of the theory of universal common ancestry. Nature 465(7295):219-222

Towns DR, Parrish GR, Tyrrell CL, Ussher GT, Cree A, Newman DG, Whitaker AH, Westbrooke I (2007) Responses of tuatara (Sphenodon punctatus) to removal of introduced Pacific rats from islands. Conserv Biol 21:1021-1031

Trewick SA (1997) Flightless NESS and phylogeny amongst endemic rails (Aves: Rallidae) of the New Zealand region. Philos Trans R Soc Lond B 352:429-446

Trewick SA, Gibbs GC (2010) Vicars, tramps and assembly of the New Zealand avifauna: a review of molecular phylogenetic evidence. Ibis 152:226-253

Trewick SA, Morgan-Richards M (2009) New Zealand biology. In: Gillespie R, Clague E (eds) Encyclopedia of islands. University of California Press, Berkeley

Trewick SA, Paterson AM, Campbell HJ (2007) Hello New Zealand. J Biogeogr 34:1-6

Turque AS, Batista D, Silveira CB, Cardoso AM, Vieira RP et al (2010) Environmental shaping of sponge associated archaeal communities. PLoS One 5(12):e15774. doi:10.1371/journal. pone. 0015774

Vaux F, Trewick SA, Morgan-Richards M (2015). Lineages, splits and divergence challenge whether the terms anagenesis and cladogenesis are necessary. Biol J Linnean Soc. doi:10.1111/ bij. 12665

Walker S, Stephens RTT, Overton JMC (2012) A unified approach to conservation prioritisation, reporting and information gathering in New Zealand. N Z J Ecol 36:243-251

Waters JM, Craw D (2006) Goodbye Gondwana? New Zealand biogeography, geology, and the problem of circularity. Syst Biol 55:351-356

Webster NS, Taylor MW, Behnam F, Luecker S, Rattei T, Whalan S, Horn M, Wagner M (2010) Deep sequencing reveals exceptional diversity and modes of transmission for bacterial sponge symbionts. Environ Microbiol 12:2070-2082

White NE, Phillips MJ, Gilbert MTP, Alfaro-Nunez A, Willerslev E, Mawson PR, Spencer PBS, Bunce M (2011) The evolutionary history of cockatoos (Aves: Psittaciformes: Cacatuidae). Mol Phylogenet Evol 59:615-622

Worthy TH, Tennyson AJD, Scofield RP (2011) An early Miocene diversity of parrots (Aves, Strigopidae, Nestorinae) from New Zealand. J Vertebr Paleontol 31:1102-1116

Wright TF, Schirtzinger EE, Matumoto T, Eberhard JR et al (2008) A multilocus molecular phylogeny of the parrots (Psittaciformes): support for a Gondwanan origin during the cretaceous. Mol Biol Evol 25:2141-2156

Zakaib GD (2011) The challenge of microbial diversity: out on a limb. Nature 476:20-21 